\title{
Chiari I Malformation Presenting with Claw Hand Deformity: An Unusual Case Report
}

\section{Pençe El Deformitesi ile Birlikte Görülen Chiari Tip 1 Deformitesi: Nadir Bir Olgu Sunumu}

\author{
Berke ARAS ${ }^{1}$, Volkan YILMAZ ${ }^{2}$
}

${ }^{1}$ Kastamonu Rehabilitation Centre, Physical Rehabilitation Medicine Clinic, Kastamonu

${ }^{2}$ Ankara Dışkapı Yıldırım Beyazıt Training and Research Hospital, Physical Rehabilitation Medicine Clinic, Ankara

\begin{abstract}
Chiari malformation (CM) is one of the most common malformations of central nervous system. It may be seen with syringomyelia, hydrocephalia and associated pathologies. We described an uncommon clinical presentation of CM in this paper. We report a case of 45 years old male patient consulted to our outpatient clinic with claw hand deformity who had misdiagnosed as ulnar entrapment neuropathy and undergone transposition surgery. We performed electroneuromyography (ENMG) to the patient and revealed normal conduction in ulnar nerve. We focused on the other causes of the deformity and found CM type-I with a syrinx cavity. We consulted the patient to neurosurgery clinic of our center for further treatment. CMI is often associated with syringomyelia. Claw hand is oftenly associated with traumatic or tumor related syrinx cavity but association with CMI is very unusual. We recommend the evaluation of such patients more carefully focusig on different causes.

Keywords: Chiari, Clawhand, Malformation
\end{abstract}

\begin{abstract}
Öz
Chiari malformasyonu (CM) santral sinir sisteminin en sık görülen malformasyonlarından birisidir. Bu durum siringomiyeli, hidrosefali ve ilișkili patolojiler ile birlikte görülebilir. Bu yazıda nadir görülen bir CM klinik bulgusu anlatılmaktadır. Daha önce ulnar sinir hasarı nedeniyle yanlış tanı konulmuş ve transpozisyon cerrahisi uygulanmış pençe el deformitesi olan 45 yaşında erkek hasta polikliniğimize pençe el deformitesi ile başvurdu. Yapılan elektronöromiyografi (ENMG) sonrasında ulnar sinirde herhangi bir iletim problemi saptanmadı. Yapılan değerlendirmede hasta sirings kavitesi olan CM tip-1 tespit edildi. Hasta ileri tedavi amaciyla beyin cerrahisi kliniğine konsulte edildi. CM tip-1 sıklıkla siringomiyeli ile birlikte görülür. Pençe el sıklıkla travmatik ya da tumor ilişkili sirinks kavitesi ile ilişkilidir ancak CM tip-1 ile birlikteliği nadirdir. $\mathrm{Bu}$ gibi hastalarda farklı sebeplerinde olabileceği akılda tutulmalidir.
\end{abstract}

Anahtar Kelimeler: Chiari, Malformasyon, Pençe El

\section{Introduction}

Chiari malformation (CM) can be defined as the herniation of posterior cranial fossa structures below foramen magnum (1). Four types of this malformation is defined. Type I CM (CMI) is the adult type and can be defined as the herniation of cerebellar tonsils, presenting in 3-4. decades mostly in women (2). CMI is inherited with autosomal dominant pattern (3). It can be presented with syringomyelia in $30-70 \%$ and hydrocephalia in 10$20 \%$ of the patients. Rare comorbidities are scoliosis, basillary invagination, Klippel- Feil syndrome and cranial fusion defects (4). CMI can be represented by headache, cervical pain, cerebellar and brainstem dysfunction like hearing loss, trigeminal and glossopharyngeal neuralgia or autonomic dysfunction symptoms (2,5-7).

In this paper, we defined a very unusual presentation of CMI with claw hand deformity.

\begin{tabular}{ll}
\hline & ORCID No \\
Berke ARAS & 0000-0002-2761-3478 \\
Volkan YILMAZ & \\
& \\
Başvuru Tarihi / Received: & 23.03 .2019 \\
Kabul Tarihi / Accepted : & 03.09 .2019 \\
& \\
Adres / Correspondence : & Berke ARAS \\
$\begin{array}{ll}\text { Kastamonu Rehabilitation } \\
\text { Medicine Clinic, Kastamonu }\end{array}$ & Centre, Physical Rehabilitation \\
e-posta / e-mail & drberkearas@gmail.com \\
\hline
\end{tabular}

Case

A 45 years old male patient was consulted to our outpatient clinic with left claw hand deformity. The history goes back two years ago when he had suffered from numbness in medial part of forearm and 4-5. fingers of left hand. The electrophysiological evaluation of the patient performed in another center had revealed ulnar nerve entrapment and the he had undergone an ulnar nerve transposition operation in neurosurgery department of the same center. His complaints had not recovered after the first operation and claw hand deformity and weakness of left hand fingers had occurred. The follow up electrophysiological evaluation of the patient after a year had revealed ulnar nerve entrapment and same operation was done.

The medical history of the patient included a ventriculoperitoneal shunt (VPS) operation after he had consulted to neurosurgery outpatient clinic of our center with headache, dizziness, imbalance and amnesia and diagnosed as CMI 12 years ago. There was no any other significant feature in medical history of the patient.

We performed another electroneuromyography (ENMG), cervical and cranial magnetic resonance imaging (MRI) to the patient. The ENMG evaluation of the patient did not reveal any ulnar nerve entrapment finding. Nerve conduction studies and needle EMG was normal (Table 1). The cranial MRI of the patient revealed CMI malformation and 
abnormalities due to previous operations. The cervical MRI of the patient revealed CMI

malformation, deformation of cervical axis, spondylolysis and syrinx cavity in lower cervical and upper thoracal spinal segments (Figure 1 and 2). temperature sensation, dysesthesia, lower limb spasticity and motor functional impairment in severe cases when the cavity extends to anterior horns of the spinal cord. Motor impairment initiates from hands and elevates proximally.

Table 1: Neddle EMG results

\begin{tabular}{|c|c|c|c|c|c|c|c|c|c|}
\hline \multirow[t]{2}{*}{ Muscles } & \multicolumn{5}{|c|}{ Spontan activity } & \multicolumn{3}{|c|}{ MUP } & \multirow{2}{*}{$\begin{array}{c}\text { Interferance } \\
\text { PATTERN }\end{array}$} \\
\hline & IA & FIB & PSW & FASE & HF & AMP & DUR & POLY & \\
\hline L.DELTOID & $\mathrm{N}$ & None & None & None & None & $\mathrm{N}$ & $\mathrm{N}$ & $\mathrm{N}$ & $\mathrm{N}$ \\
\hline R.ADM & $\mathrm{N}$ & None & None & None & None & $1+$ & $1+$ & $1+$ & $2-$ \\
\hline R.APB & $\mathrm{N}$ & None & None & None & None & $1+$ & $1+$ & $1+$ & $2-$ \\
\hline R.EI & $\mathrm{N}$ & None & None & None & None & $1+$ & $1+$ & $1+$ & $2-$ \\
\hline
\end{tabular}

N: Normal, IA: insertional activity, FIB: fibrilation, PSW: Positif sharp wave, FASE: fasiculation, MUP: motor unit potential, AMP: amplitude , DUR: duration POLY: polyphasia ADM: abductor digiti minimi APB:abductor pollicis brevis EI:extensor indicis

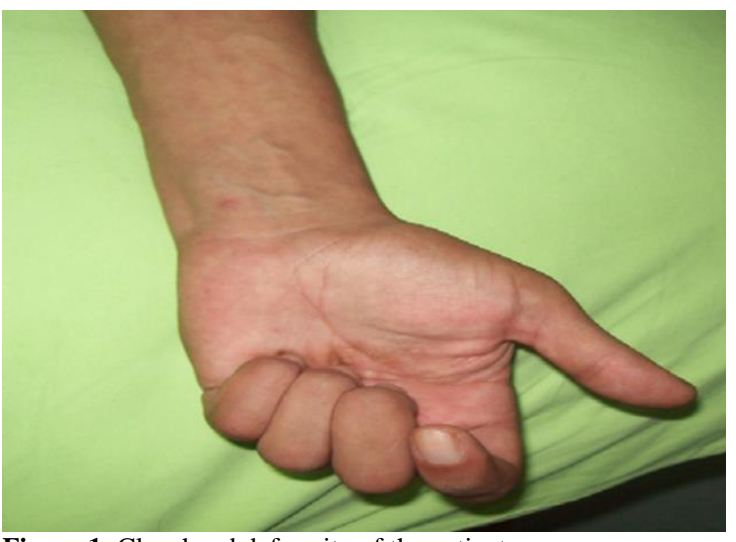

Figure 1: Claw hand deformity of the patient

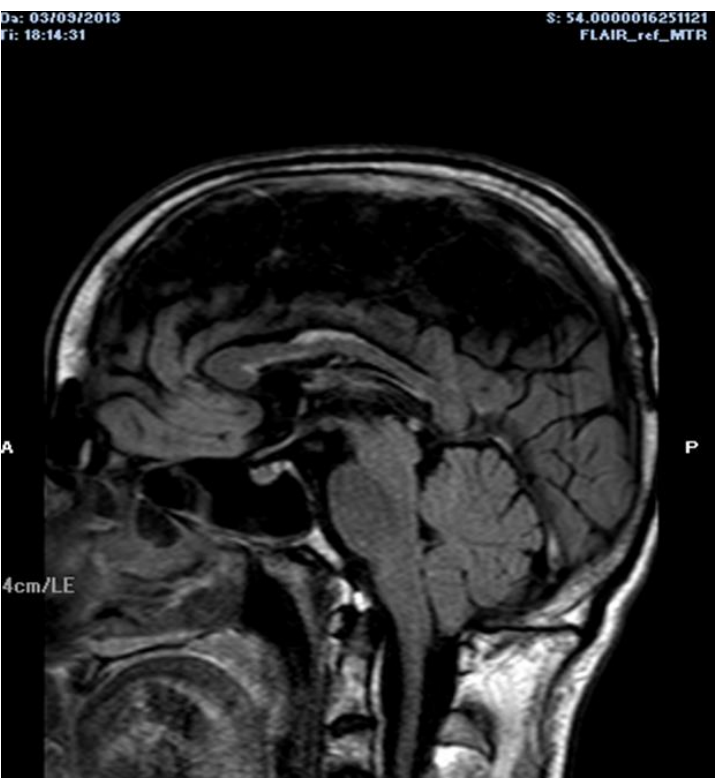

Figure 2: CMI malformation and postoperative degeneration findings with VPS of the patient (flair T1)

\section{Discussion}

CMI can be presented with different clinical manifestations and comorbid abnormalities like syringomyelia. Symptoms of syrinx include sensory loss associated with impairment of pain and
Claw hand deformity is characterized by flexion deformity in 3-4-5th digits of hand. It can be associated with congenital anomalies like muscular atrophies or acquired as a result of ulnar entrapment, leprosy or syringomyelia (8-10). The association of this deformity with syringomyelia is often tumor related (11) or traumatic syrinx (12). The association between CMI related syrinx is very rare and unusual. We did not find any case report of CMI associated claw hand deformity except the case reported by Pettorini et al. and to our best knowledge this is the second case report in the literature (13). The unique feature of our case is the misdiagnosis of ulnar entrapment neuropathy with ENMG.

The association of CMI and deformities like claw hand is often misdiagnosed. The incidence of such abnormalities may be more often. Further studies are required to clarify the real incidence. We recommend the evaluation of such patients more carefully focusing on different causes.

Written consent: Written consent of the patient was obtained on 18/12/2018.

\section{References}

1. Novegno F, Caldarelli M, Massa A, et al. The natural history of the Chiari type I anomaly. J Neurosurg Pediatr. 2008;2:179-87.

2. Da Silva JA, Brito JC, da Nobrega PV. Autonomic nervous system disorders in 230 cases of basilar impression and Arnold-Chiary deformity. Neurochirurgia (Stuttg). 1992;35:183-8.

3. Cavender RK, Schmidt JH. Tonsillar ectopia and Chiari malformations: Monozygotic triplets: Case report. J Neurosurg. 1995;82:497-500.

4. McGirt MJ, Attenello FJ, Atiba A, et al. Symptom recurrence after suboccipital decompression for pediatric Chiari I malformation: analysis of 256 consecutive cases. Childs Nerv Syst. 2008;24:1333-9.

5. Dolgun H, Turkoglu E, Kertmen H, et al. Chiari Type I malformation presenting with bilateral hearing loss. J Clin Neurosci. 2009;16:1228-30.

6. Rosetti P, Ben Taib RO, Brotchi J, et al. Arnold Chiari Type 1 malformation presenting as a trigeminal neuralgia: Case Report. Neurosurgery. 1999;44:1122-4.

7. Kanpolat Y, Unlu A, Savas A, et al. Chiari Type 1 malformation presenting as a gloosopharyngeal neuralgia: Case Report. Neurosurgery. 2001;48:226-8. 
8. Pareyson D, Marchesi C. Diagnosis, natural history, and management of Charcot-Marie-Tooth disease. Lancet Neurol. 2009;8:654-67.

9. Neiman R, Maiocco B, Deeney VF. Ulnar nerve injury after closed forearm fractures in children. J Pediatr Orthop. 1998; $18: 683-5$

10. Malaviya GN. Correction of claw fingers in leprosy-current status. Acta Leprol. 1991;7:389-95.
11. Shenoy SN, Raja A. Cystic cervical intramedullary schwannoma with syringomyelia. Neurology India. 2005;53:224-5.

12. Bains RS, Althausen PL, Gitlin GN, et al. The role of acute decompression and restoration of spinal alignment in the prevention of post-traumatic syringomyelia: case report and review of recent literature. Spine. 1976;26:399-402.

13. Pettorini LB, Oesman C, Magdum S. New presenting symptoms of Chiari I malformation: report of two cases. Childs Nerv Syst. 2010;26:399-402. 